\title{
Production and quality assessment of functional yoghurt enriched with coconut
}

\author{
Joel Ndife ", Felicia Idoko, Rabiu Garba \\ Department of Food Technology, Kaduna Polytechnic, Kaduna, Nigeria
}

Email address:

jothe12000@yahoo.com (J. Ndife)

\section{To cite this article:}

Joel Ndife, Felicia Idoko, Rabiu Garba. Production and Quality Assessment of Functional Yoghurt Enriched with Coconut. International Journal of Nutrition and Food Sciences. Vol. 3, No. 6, 2014, pp. 545-550. doi: 10.11648/j.ijnfs.20140306.19

\begin{abstract}
The potential of producing acceptable symbiotic yoghurt enriched with coconut-cake was investigated. Yoghurt samples A (Control), B, C and D were produced at $0 \%, 10 \%, 20 \%$, and $30 \%$ of milk substitutions with coconut-cake. The physico-chemical, microbial and sensory analyses were determined to ascertain the quality attributes of the products. The results of physico-chemical analysis obtained showed increase in values for $\mathrm{pH}$ (4.32-4.45), specific gravity (1.03-1.14), soluble solids (7.10-10.47\%) and sweetness index (10.60-20.13). There were also remarkable increase in the proximate values for moisture $(80.10-85.23 \%)$, fat (1.50-3.13\%), fibre $(0.2-2.18 \%)$ and ash $(0.53-1.01 \%)$. A reverse trend was observed for acidity, total solids, protein and carbohydrate values in enriched yoghurts. The microbial analysis showed no presence of coliform bacteria. The total microbial count was highest in sample B $\left(8.0 \times 10^{5}\right)$ while sample A had the highest lactic acid bacteria count $\left(6.4 \times 10^{3} \mathrm{cfu} / \mathrm{ml}\right)$. The sensory evaluation result showed significant differences $(0.05<\mathrm{p})$ in all the organoleptic attributes analysed. Sample D with $30 \%$ coconut inclusion had the highest overall acceptability score.
\end{abstract}

Keywords: Yoghurt, Physico-Chemical, Microbial, Sensory

\section{Introduction}

Functional foods refer to processed food containing ingredients that aid specific bodily functions in addition to being nutritious (Lourens-Hattingh and Viljoen, 2001; Gibson and Roberfroid, 1995). Functional foods are developed specifically to promote health or reduce the risk of diseases. Examples of functional foods include foods that contain specific minerals, vitamins, fatty acids or dietary fibres. Foods with added biologically active substances such as phytochemicals and those that can support beneficial microbial cultures of interest also fall into this category (Ndife and Abbo, 2009).

Recent researches are shifting focus to diverse components in dairy foods, particularly fermented dairy products. Probiotics and prebiotics are evolving nutritional concepts in the development of dairy functional foods. Probiotics are defined as live microbial food ingredients which benefically affects the host animal by improving its intestinal microbial balance (Lourens-Hattingh and Viljoen, 2001; Gibson and Roberfroid, 1995). While prebiotics are non-digestible foods that make their way through our digestive system and help desirable gut bacteria to grow and flourish (Staffolo et al, 2004; Gibson and Roberfroid, 1995; Aryana et al, 2007). Although a lot of health benefits have been attributed to probiotics, their anticarcinogenic, hypocholesterolemic and antagonistic actions against enteric pathogens and other intestinal organisms have received the most attention (Seckin et al., 2009; Abd El-Gawad, 2004).

Yoghurt, as a fermented diary product is regarded as a probiotic carrier, is nutritionally rich in available protein, calcium, milk fat, potassium, magnesium, vitamin $\mathrm{B}_{2}, \mathrm{~B}_{6}$ and vitamin $\mathrm{B}_{12}$ (Lourens-Hattingh and Viljoen, 2001; Staffolo et al., 2004). It has nutritional benefits beyond those of milk, because people who are moderately lactose intolerant can enjoy yoghurt without ill effects, as most of the lactose in the milk precursor has been converted to lactic acid by the bacterial culture (Heyman, 2000; Vesa et al., 2000). Yoghurt also has medical uses because of the probiotic characteristics, in helping out on a variety of gastro intestinal conditions and in preventing antibiotic associated diarrhea (LourensHattingh and Viljoen, 2001; Mazahreh and Ershidat, 2009). Yoghurt is believed to promote good gum health, facilitates the absorption of calcium, thus preventing osteoporosis, possibly because of the probiotic effect of lactic acids presents in yoghurt (Kerry et. al., 2001). 
Contrary to widely held opinion, the coconut (Cocos nucifera L.) provides nutritious sources of meat, Juice, milk and oil. It is classified as a "functional food" because it provides many health benefits beyond its nutritional content, due to its fiber and oil content (Sanful, 2009). The oil is known to contribute to improved insulin secretion and the utilization of blood glucose; reduce symptoms associated with malabsorption syndrome and cystic fibrosis; help to relieve symptoms associated with crohn's disease; ulcerative colitis and stomach ulcers; improve the utilization of essential fatty acids and protect them from oxidation (Seow and Gwee, 1997; Sanful Rita, 2009).

Nutritionally, coconut oil is composed predominately of medium-chain fatty acids (MCFA) also known as mediumchains triglcerides (MCT), unlike the long chain fatty acids (LCFA) of saturated and unsaturated oils found in meat, milk, egg and some vegetable oils (Seow and Gwee, 1997). MCFA are very different from LCFA, because they do not have negative effect on cholesterol and help to lower the risk of both arthrosclerosis and heart diseases (Imele and Atemnkeng, 2001; Belewu et al, 2010).

In order to make yoghurt processing attractive and the product affordable, quite a number of process manipulations have been adopted including evaporation or concentration, addition of solids in the form of dry skim milk powder, use of high temperature processing to denature whey proteins to modify their water binding capacity and selection of appropriate starter cultures to make the yoghurt thick and free from whey separation. (Bille and Keya, 2002).

Current trends and changing consumer needs indicate a great opportunity for innovations and developments in fermented milks (Khurana and Kanawjia, 2007; Gad et al, 2010). There is little information about fiber fortification in cultured dairy products however various fibers like psyllium, guar gum, gum acacia, oat fiber, and soy components have potentials to be used (Staffolo et al, 2004; Khurana and Kanawjia, 2007). Therefore, consuming symbiotic foods that contain prebiotics (fibres) and probiotics (lactic acid bacteria) would offer added nutritional benefits that can help boost overall health and well-being.

Thus, the objective of this study is to produce functional yoghurt enriched with coconut and to determine the physicochemical, microbial, sensory qualities and overall acceptability of the product.

\section{Materials and Methods}

\subsection{Raw Material Procurement}

The coconut fruit and commercial powdered full cream (Dano) milk were obtained from Kaduna main market in Nigeria. The freeze-dried starter culture was also purchased from a chemical supermarket in Kaduna. Portable water was strictly used throughout this experiment.

\subsection{Production of Enriched Coconut Yoghurt}

The coconuts were peeled to remove the outer brown skin and then washed with portable water to remove all dirt. They were then chopped into pieces before grating to fine particles and blended with the powdered milk at different levels of powdered milk substitution of $0 \%, 10 \%, 20 \%$ and $30 \%$, using water to produce milk-slurries. These were labeled as samples A (control), B, C and D respectively (Table 1).

Table 1. Formulation of enriched yoghurts

\begin{tabular}{lllll}
\hline Yoghurt samples & & & & \\
\hline Ingredients & A & B & C & D \\
\hline Coconut cake (g) & 0 & 10 & 20 & 30 \\
Milk powder (g) & 100 & 90 & 80 & 70 \\
Water (ml) & 1000 & 1000 & 1000 & 1000 \\
Starter culture (g) & 0.5 & 0.5 & 0.5 & 0.5 \\
\hline
\end{tabular}

The coconut-milk mixtures were heated to about $85^{\circ} \mathrm{C}$ to kill any undesirable bacteria and to partially break down the milk proteins. The samples were then cooled to about $44^{\circ} \mathrm{C}$. Commercial freeze-dried mixed culture $(0.5 \mathrm{~g})$ of $L$. bulgaricus and $S$. thermophilus was added to $5 \mathrm{ml}$ sterile warm water to activate the organisms. This active culture was used to inoculate each of the 1litre $(1,000 \mathrm{ml})$ coconutmilk slurries, at the same temperature of $44^{0} \mathrm{C}$ which was maintained for 4-7 hours to allow for fermentation and the rapid production of lactic-acid by the inoculated bacteria, which led to the coagulation of the milk. The yoghurts produced were cooled rapidly to $8-10^{\circ} \mathrm{C}$ and refrigerated for subsequent analysis.

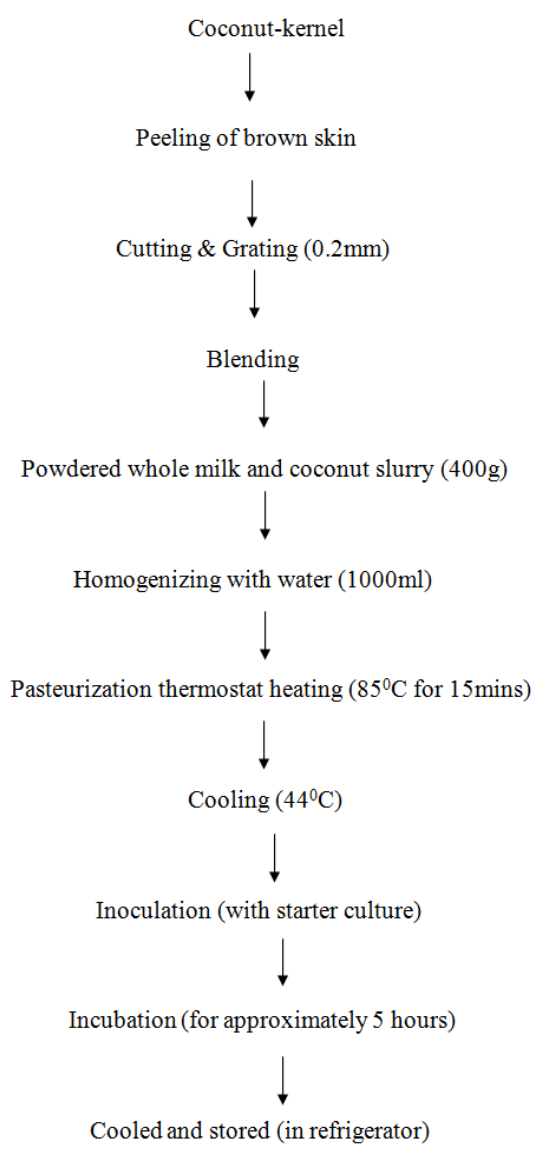

Figure 1. Flow chart of enriched coconut yoghurt 


\subsection{Physico-Chemical Analysis}

The $\mathrm{pH}$, brix (soluble solids) and specific gravity of the yoghurt samples were measured using standardized instrumental methods (AOAC, 2000). The acidity was determined by titration against $0.1 \mathrm{M}$ sodum hydroxide using phenolphalein as indicator (Jacobs, 1999). The sweetness and astringency indexes were calculated as the ratio of soluble solids to acidity and vice versa (Wardy et al., 2009). The proximate composition of the yogurt samples were also determined as described by AOAC (2000) methods: The moisture contents by indirect distillation drying method; Ash content by the muffle furnace ignition method; Fat content through the solvent extraction method in a continuous reflux system using the soxtlet apparatus. The protein contents were determined by the formal titration method, while the carbohydrate and energy contents were determined by recommended mathematical procedures.

\subsection{Microbiological Analysis}

The determination of the microbial contamination in the yoghurts was performed by using the plate count agar for the total viable bacteria counts, MacConkey agar for the coliform counts and selective enriched media of Man Rogosa Sharpe (MRS) agar for the lactic acid bacteria counts, as outlined in compendium of methods for the microbiological examination of foods (AMPH, 1992) with some modifications. The colonies were counted using a colony counter and the result was expressed as colony forming unit per $\mathrm{ml}$. (cfu/ml).

\subsection{Sensory Analysis}

Sensory evaluation of the yoghurt samples were carried out by 20 panelists on a 9 point hedonic scale for different parameters such as colour, aroma, taste, consistency/texture and overall acceptability as described by Ihekoronye and Ngoddy (1985).

\subsection{Statistical Analysis}

Data obtained from the sensory analysis of the samples were evaluated statistically using a variance analysis (ANOVA) and the Duncan Multiple range test (Iwe, 2010).

\section{Results and Discussion}

\subsection{Physico-Chemical Properties}

The physico-chemical parameters analysed for the yoghurt samples are summarised in Table 1.

The $\mathrm{pH}$ values of the yoghurt samples ranged from 4.32 to 4.50. Sample A (plain-yoghurt) had the lowest value, when compared with the coconut enriched samples (B, C and D). Lactic acid bacteria produce lactic acid during fermentation of milk- lactose, thus lowering the $\mathrm{pH}$ (Eke et al, 2013). Food Standard Code requires that the $\mathrm{pH}$ of yoghurt be a maximum of 4.50 in order to prevent the growth of any pathogenic organisms (Donkor et al., 2006).

The Titratable acidity also ranged from 0.52 to $0.67 \%$ in the yoghurt samples. The enriched-yoghurt samples had lower acidity values $(0.59 \%)$ than plain-yoghurt $(0.67 \%)$. This could be due to more availability of lactose to the fermenting microbes. Estevez et al, (2010) also reported that higher total solids led to more acid production than lower total solids in soy yoghurts. However, these values are within the average of $0.6 \%$ acidity recommended for plain yoghurts (Eke et al, 2013).

The total solids decreased in yoghurt samples enriched with coconut-cake by an average of $21.42 \%$. The total solids are an indication of the dry matter content of the yoghurt samples (Belewu et al., 2010; Khalifa et al 2011). However, sample D with $30 \%$ enrichment had the highest soluble solids content $(10.47 \%)$. This can be mainly attributed to the contribution of monosaccharide-sugars from coconut addition. Carbohydrate monohydrates are abundant in coconut copra and the milk and are responsible for their sweet taste (Sanful, 2009; Belewu et al., 2010).

Table 2. Physico-chemical properties of enriched yoghurts

\begin{tabular}{lllll}
\hline Yoghurt Samples & & & & \\
\hline Parameters & A & B & C & D \\
\hline Acidity (\%) & $0.67 \pm 0.30$ & $0.62 \pm 0.25$ & $0.64 \pm 0.35$ & $0.52 \pm 0.30$ \\
pH & $4.32 \pm 0.10$ & $4.42 \pm 0.15$ & $4.45 \pm 0.10$ & $4.50 \pm 0.15$ \\
Specific gravity & $1.03 \pm 2.53$ & $1.06 \pm 2.24$ & $1.10 \pm 2.30$ & $1.14 \pm 2.01$ \\
Soluble solids (\%) & $7.10 \pm 2.01$ & $8.26 \pm 2.05$ & $8.53 \pm 1.80$ & $10.47 \pm 1.93$ \\
Solids non fat (\%) & $18.40 \pm 0.60$ & $15.755 \pm 0.50$ & $13.35 \pm 0.45$ & $11.82 \pm 0.65$ \\
Total solids (\%) & $19.90 \pm 0.41$ & $17.92 \pm 0.35$ & $16.48 \pm 0.50$ & $14.77 \pm 0.46$ \\
Sweetness Index & $10.60 \pm 0.52$ & $13.32 \pm 0.43$ & $13.33 \pm 0.52$ & $20.13 \pm 0.45$ \\
Astringency Index & $0.09 \pm 0.03$ & $0.07 \pm 0.02$ & $0.07 \pm 0.02$ & $0.05 \pm 0.02$ \\
\hline
\end{tabular}

${ }^{\text {a }}$ Data are mean values of duplicate determinations \pm standard deviation

Specific gravity also increased with coconut enrichment. This could be attributed to increased total solids (soluble and insoluble) because of the coconut-cake addition (Alakali et al., 2008). Imele and Atemnkeng (2001) and Sanful Rita (2009) also reported increased fat content, specific gravity and total solids with the addition of coconut milk to plain- yoghurt.

The sweetness and sourness indexes in enriched yoghurts were of the ranges 13.32 to 20.13 and 0.07 to 0.05 respectively and differed when compared with plain-yoghurt B (10.60 and 0.09). The sourness of the yoghurts expresses the level of astringency produced as a result of the 
production of lactic acid by the action of Lactobacillus lactic on lactose in the substrates (Sanful, 2009). The tartness and sweetness of acid foods is reported to greatly influence sensory perception (Adeola and Aworh, 2010).

\subsection{Proximate Composition}

Table 3 shows the result of the proximate analysis of the different yoghurt samples evaluated in this study. The composition of foods is known excert considerable influence on their physical, nutritional, sensory and shelf characteristics (Prodaniuc, 2009; El Bakri and Zubeir, 2009).

The moisture content of the yoghurt samples ranged between 80.10 to $85.23 \%$.This was dependent on the proportion of milk powder to coconut cake used. Plainyoghurt (sample A) had the lowest moisture value $(80.10 \%)$ compared to the enriched yoghurts. The moisture contents of the yoghurt samples fell within the range of most commercial yoghurts $(80-86 \%)$.

The protein content was between the ranges of 2.17 to $3.05 \%$ in all yoghurt samples. The protein content decreased as the proportion of the coconut-cake increased in the yogurts, with the highest of $3.05 \%$ in the $100 \%$ plain-yoghurt to an average of $2.31 \%$ in the coconut-enriched yoghurts.

The fat content ranged between 2.17 to $3.13 \%$ in the enriched yoghurts compared to milk-yoghurt sample A $(1.50 \%)$. The fat contents of the enriched yoghurts were above the standard for low fat yoghurts $(<3.5 \%)$ (Saint-Eve, 2008). Fat content has been reported by other researchers to have positive influence on the physical and sensory characteristics (Bille and Keya, 2002; Marinescu and Pop, 2009) and negative impact on the shelf stability of yogurts (Saint-Eve, 2008; Farinde et al, 2009).

The ash content also increased as the proportion of coconut-cake increased in the yoghurts. This could be due to the fact that coconuts have high ash content and minerals by implication (Imele and Atemnkeng, 2001; Marinescu and Pop, 2009).

The high ash values in the coconut enriched yoghurts agree with results on other plant substituted yoghurts by other researchers (Belewu et al, 2010; Eke et al, 2013).

There was increased fibre content in the enriched-yoghurts by $1.68 \%$ compared to milk-yoghurt $(0.02 \%)$. Coconut-cake contains fibres (soluble and insoluble) which are indigestible polysaccharides that could assist in the viscousity and stabilization of the yoghurts, in addition to serving as prebiotics (Sanful Rita, 2009; Belewu et al, 2010).

The carbohydrate content of the yoghurt samples increased with coconut supplementation from $14.62 \%$ in plain-yoghurt (sample A) to $8.71 \%$ in enriched-yogurts. This was derivable from the coconut-cake which is known to be rich in carbohydrate (Imele and Atemnkeng, 2001; Sanful, 2009).

Table 3. Proximate analysis of enriched yoghurts

\begin{tabular}{lllll}
\hline Yoghurt samples (\%) & & & & \\
\hline Parameters & A & B & C & D \\
\hline Moisture & $80.10 \pm 0.28$ & $82.08 \pm 0.25$ & $83.52 \pm 0.20$ & $85.23 \pm 0.30$ \\
Protein & $3.05 \pm 0.40$ & $2.46 \pm 0.50$ & $2.31 \pm 0.30$ & $2.17 \pm 0.40$ \\
Fat & $1.50 \pm 0.20$ & $2.17 \pm 0.20$ & $3.13 \pm 0.15$ & $2.95 \pm 0.20$ \\
Crude Fibre & $0.20 \pm 0.46$ & $1.05 \pm 0.35$ & $1.83 \pm 0.42$ & $2.18 \pm 0.45$ \\
Ash & $0.53 \pm 0.20$ & $0.80 \pm 0.15$ & $0.96 \pm 0.25$ & $1.01 \pm 0.15$ \\
Carbohydrate & $14.62 \pm 0.60$ & $11.44 \pm 0.40$ & $8.25 \pm 0.55$ & $6.46 \pm 0.60$ \\
\hline
\end{tabular}

Data are mean values of duplicate determinations \pm standard deviation

\subsection{Microbial Content}

The microbial content of of the yoghurt samples analysed are shown in table 4.

The results of the total microbial counts (TVC) did not show a particular pattern in relation to the yoghurts. Sample $\mathrm{B}$ with $10 \%$ enrichment had the highest microbial load $\left(8.0 \pm 0.25 \times 10^{5} \mathrm{cfu} / \mathrm{ml}\right)$ followed by sample A $\left(5.2 \pm 0.31 \times 10^{5}\right.$ $\mathrm{cfu} / \mathrm{ml})$. The microbial status of the yoghurts were within acceptable standard $<1 \times 10^{6} \mathrm{cfu} / \mathrm{ml}$ (Lourens-Hattingh and Viljoen, 2001; El Bakri and Zubeir, 2009).

The absence of coliform bacteria (TCC) signifies that the yoghurt samples are free from faecal contamination due the hygienic conditions employed during production (Osundahunsi et al., 2007).

Total lactobacilli counts (TLC) was created for bacteria causing fermentation and coagulation in milk and defined as those which produce Lactic acid from lactose (Mazahreh and
Ershidat, 2009; El Bakri and Zubeir, 2009). The lactobacilli bacteria were more prevalent in sample A $\left(6.4 \pm 0.53 \times 10^{3}\right.$ $\mathrm{cfu} / \mathrm{ml})$ than in the enriched yoghurts $\left(2.1 \pm 0.20 \times 10^{3} \mathrm{cfu} / \mathrm{ml}\right)$. Lactobacilli preferentially feed on lactose from milk before its degradation of carbohydrates as supplementary energy source (Prodaniuc, 2009; Farinde et al., 2009) hence the higher Lactobacilli counts in plain yoghurt (sample A). The high lactobacilli count in the enriched yoghurts is suggestive of its viability with coconut enrichment (El Bakri and Zubeir, 2009). Lactobacillus and Bifidobacterium species are the most commonly used probiotics in dairy functional foods (Ndife and Abbo, 2009; Yuliana et al, 2010). Moreover their ability to utilize coconut fibre as feed stock (prebiotics) is in dare need of further research in the development of symbiotic functional yoghurts (Khurana and Kanawjia, 2007; Yuliana et al, 2010). 
Table 4. Microbial analysis of enriched yoghurts

\begin{tabular}{lllll}
\hline Yoghurt samples (cfu/ml) & & & & \\
\hline Parameters & A & B & C & D \\
\hline TVC & $5.2 \pm 0.31 \times 10^{5}$ & $8.0 \pm 0.25 \times 10^{5}$ & $6.5 \pm 0.26 \times 10^{5}$ & $4.3 \pm 0.15 \times 10^{5}$ \\
TCC & Nil & Nil & NIL & NIL \\
TLC & $6.4 \pm 0.53 \times 10^{3}$ & $2.5 \pm 0.28 \times 10^{3}$ & $1.8 \pm 0.26 \times 10^{3}$ & $1.3 \pm 0.20 \times 10^{3}$ \\
\hline
\end{tabular}

TVC-Total Viable Counts; TCC- Total Coliform counts; TLC- Total Lactobacilli Counts; ${ }^{b}$ Data are mean values of duplicate determinations \pm standard deviation

\subsection{Sensory Evaluation}

The mean sensory scores of the organoleptic evaluation and acceptability for the different yoghurt samples are shown in Table 6. The statistical analysis revealed that there were significant differences $(\mathrm{p}<0.05)$ among the yoghurt samples in the sensory attributes observed.

Sample A (plain yoghurt) had the highest score (8.55), while sample $C$ had the lowest score (7.25) for colour. The appearance was influenced by colour-appeal, the panelists showed preference for the lighter colour of sample A without coconut enrichment.

The enrichment of the yoghurts with coconut-cake resulted in better taste and aroma scores. Sample D had the highest scores of 8.75 and 8.35 for both taste and aroma, while sample A (plain yoghurt) had the lowest scores of 6.50 and 6.60 for taste and aroma respectively. Most of the panelist appreciated the coconut flavour which was attributed to the oil content. Saint-Eve, (2008) reported that fat content had a considerable influence on the sensory and instrumental characteristics of yogurt, because the oil acts as an aroma solvent and has better rheology compared to low fat and skimmed yogurts. The high flavour values could also be due to increased sweetness imparted by the high carbohydrate content of coconut-cake (Gad et al., 2010). Sanful (2009), reported that flavour and aroma scored higher rating for increased coconut-milk input in the production of yoghurt.

The sensory scores for mouth-feel as it relates to texture (viscousity) and consistency were affected by the enrichment of yoghurt (Staffolo et al., 2004). The enriched yoghurts had lower scores cookie than the plain yoghurt (8.14) mainly due to their poor consistency (flowing nature).

Enriched yoghurt samples C and D with 20 and 30\% coconut substitution had the best overall acceptability ratings of 7.45 and 8.35 respectively. The panelists appreciated the increased viscousity and cherished the chew ability as a factor before swallowing, in the enriched yoghurts. Other research works on coconut substitution in yoghurt products showed similar consumer preference for coconut sweetness and flavours (Imele and Atemnkeng , 2001; Sanful, 2009; Gad et al., 2010)

Table 5. Sensory analysis of enriched yogurts

\begin{tabular}{lllll}
\hline Yoghurt samples & & & & \\
\hline Parameters & A & B & C & D \\
\hline Colour & $8.55^{\mathrm{a}}$ & $7.75^{\mathrm{b}}$ & $7.35^{\mathrm{b}}$ & $7.25^{\mathrm{b}}$ \\
Taste & $6.50^{\mathrm{c}}$ & $7.62^{\mathrm{b}}$ & $8.15^{\mathrm{b}}$ & $8.75^{\mathrm{a}}$ \\
Aroma & $6.60^{\mathrm{c}}$ & $7.58^{\mathrm{b}}$ & $7.95^{\mathrm{a}}$ & $8.35^{\mathrm{a}}$ \\
Mouth-feel & $8.14^{\mathrm{a}}$ & $7.50^{\mathrm{b}}$ & $6.54^{\mathrm{c}}$ & $6.13^{\mathrm{c}}$ \\
Overall acceptability & $6.60^{\mathrm{c}}$ & $7.25^{\mathrm{b}}$ & $7.45^{\mathrm{b}}$ & $8.35^{\mathrm{a}}$ \\
\hline
\end{tabular}

*Means within a row with different letters are significantly different at $\mathrm{P}<0.05$.

\section{Conclusion and Recomendations}

This study observed that the enriched coconut yoghurt produced to be nutritionally and sensorially superior in most quality attributes than the conventional yoghurt. Thus coconut-cake can be used to produce symbiotic functional yoghurt with both probiotic and prebiotic properties which would be acceptable.

However further research is needed to improve on the survival of the probiotics by the modification of the production process and exploring different storage conditions. Better selection of probiotic starter cultures and the application of micro-encapsulation techniques (protective coating of microorganisms) are hereby recommended as alternate means.

\section{References}

[1] Abd El-Gawad A.I, El-Sayed E, Hafez S, El-Zeini H and Saleh F (2004). Inhibitory effect of yoghurt and soya yoghurt containing bifidobacteria on the proliferation of ehrlich ascites tumour cells in vitro and in vivo in a mouse tumour model. British Journal of Nutrition, 92: 81-86.

[2] Adeola A.A and Aworh O.C (2010). Development and sensory evaluation of an improved beverage from Nigeria's tamarind (tamarindus indica 1.) fruit. J. Food Agric. Nutr. Dev. 10(9):4079-4093.

[3] Alakali, J. S., Okonkwo, T. M and Iordye, E. M. (2008). Effect of stabilizers on the physico-chemical and sensory attributes of thermized yoghurt African Journal of Biotechnology Vol. 7 (2): 158-163. 
[4] AMPH. (1992). Compendium of methods for the microbiological examination of foods. Washington DC: American Public Health Association.

[5] AOAC (2000). Official Methods of Analysis, 17th ed. Association. of Official Analytical Chemists. Washington, D.C.

[6] Aryana, K.J., Plauche, S., Rao, R.M., McGrew, P. and Shah, N.P. (2007). Fat-free plain yogurt manufactured with inulins of various chain lengths and Lactobacillus acidophilus. J. Food Sci., 72:79-84.

[7] Belewu, M.A., Belewu, K.Y and Bamidele, R.A. (2010). Cyper-coconut yoghurt: preparation, compositional and organoleptic qualities. African Journal of Food Science and Technology Vol. 1(1) : 010-012.

[8] Bille P and Keya E (2002). A Comparison of Some Properties of Vat-Heated and Dry Skim Milk Powder Fortified Set Yoghurts. The Journal of Food Technology in Africa, Vol. 7(1): 21-23.

[9] Donkor N O, Henriksson A, Vasiljevic T, and Shah N, (2006). Effect of acidification on the activity of probiotics in yoghurt during cold storage International Dairy Journal 16: 1181-1189.

[10] Eke, M.O, Olaitan, N.I and Sule, H.I (2013). Nutritional evaluation of yoghurt-like product from baobab (Adansonia digitata) fruit pulp emulsion and the micronutrient content of baobab leaves. Advance Journal of Food Science and Technology, 5(10): 1266-1270.

[11] El Bakri J.M and Zubeir E.M (2009). Chemical and microbiological evaluation of plain and fruit yoghurt in khartoum state sudan. International Journal of Dairy Science, 4(1): 1-7.

[12] Estevez A, Mejía J, Figuerola F and Escobar B (2010). Effect of solid content and sugar combinations on the quality of soymilk-based yogurt. Journal of Food Processing and Preservation, 34: 87-97.

[13] Farinde O.E, Adesetan T, Obatolu V and Oladapo M (2009). Chemical and microbial properties of yogurt processed from cow's milk and soymilk. Journal of Food Processing and Preservation, 33: 245-254.

[14] Gad A.S, Kholif A.M and Sayed A.F (2010). Evaluation of the nutritional value of functional yogurt resulting from combination of date palm syrup and skim milk. American Journal of Food Tech. 5(4): 250-259.

[15] Gibson, G.R. and Roberfroid, M.R. (1995). Dietary modulation of the human colonic microbial: Introducing the concept of prebiotics. J. Nutr., 125(6), 1401-1412.

[16] Heyman M (2000). Effect of lactic acid bacteria on diseases. J. Am. Coll. Nutr., 9: 137-146.

[17] Ihekoronye A. I and Ngoddy, P. O (1985) Integrated Food Science and Technology for the Tropics. (2nd ed.) Macmillan Publishers Ltd. London.

[18] Imele H and Atemnkeng A (2001). Preliminary study of the utilisation of coconut in yoghurt production. The Journal of Food Technology in Africa, Vol. 6(1): 11-12.

[19] Iwe M.O (2010). Handbook of Sensory Methods and Analysis. Rojoint Communication Services Ltd., Enugu. PP 75-78.

[20] Jacobs B.M (1999). The Chemical Analysis of Foods and
Food Products. 3rd ed. CBS Publishers and Distributors. New Delhi, India.

[21] Khalifa M, Elgasim A, Zaghloul A, and Maufouz M. (2011). Application of inulin and mucilage as stabilizers in yoghurt production. American Journal of Food Technology, Vol.1: 1017.

[22] Kerry,A, Jackson B and Dennis A (2001). Lactose maldigestion, calcium intake and osteoporosis in african, asian and hispanic-americans. J. Am. Coll. Nutr., 20: 198-205.

[23] Khurana H and Kanawjia S (2007). Recent Trends in Development of Fermented Milks. Current Nutrition \& Food Science, 2007, 3, 91-108.

[24] Lourens-Hattingh A and Viljoen B (2001). Review: Yogurt as probiotic carrier food. International Dairy Journal, 11: 1-17.

[25] Marinescu, A and Pop, F (2009). Variation in physicochemical parameters of probiotic yogurt during refrigeration storage. Carpathian Journal of Food Science and Technology, Vol. 1(2):18-26.

[26] Mazahreh, A.S and Ershidat, M.O (2009). The benefits of Lactic acid bacteria in yoghurt on the gastrointestinal function and health. Pakistan Journal of Nutrition 8 (9):1404-1410.

[27] Ndife J and Abbo E (2009). Functional Foods: Prospects and Challenges in Nigeria. Journal of Science \&Technology. Vol.1 (5): 1-6.

[28] Osundahunsi O, Amosu D, and Ifesan B (2007). Quality evaluation and acceptability of soy-yoghurt with different colours and fruit flavours. American Journal of Food Technology. 2(4): 273-280.

[29] Prodaniuc Natalia (2009). Study regarding some physicalchemical characteristics of the yoghurt with red beetroot juice. Carpathian Journal of Food Science and Technology, I (2): 44-49.

[30] Sanful Rita (2009). Promotion of coconut in the production of yoghurt. African Journal of Food Science Vol.3 (5): 147-149.

[31] Saint-Eve A., Levy C, Le Moigne M, Ducruet V, Souchon I (2008). Quality changes in yogurt during storage in different packaging materials. Food Chemistry 110: 285-293.

[32] Seckin K A, Ergonul B, Tosun H and Ergonul P (2009). Effects of Prebiotics (Inulin and Fructooligosaccharide) on Quality Attributes of Dried Yoghurt (Kurut) Food Sci. Technol. Res., 15 (6), $605-612$.

[33] Seow CC and Gwee CN (1997). Coconut milk: chemistry and technology. Int. J. Food Sci. Technol., 32 : 189-201.

[34] Staffolo, M.D., Bertola, N., Martino, M. and Bevilacgua, Y.A. (2004). Influence of dietary fiber addition on sensory and rheological properties of yogurt. Int. Dairy J., 14, 263-268.

[35] Vesa, T,H , Marteau and Korpela R (2000). Lactose intolerance J. am. Coll. Nutr., 129: 165-175.

[36] Wardy W, Saalia F, Steiner-Asiedu M, Budu A and SefaDedeh S(2009). A comparison of some physical, chemical and sensory attributes of three pineapple (Ananas comosus) varieties grown in Ghana. African Journal of Food Science Vol. 3(1): 022-025.

[37] Yuliana N, Rangga A and Rakhmiati (2010). Manufacture of fermented coco milk-drink containing lactic acid bacteria cultures. African Journal of Food Science Vol. 4(9): 558 - 562 